ISSN 1978-2071 (Print); ISSN 2580-5967 (Online) Jurnal IImiah Kedokteran Wijaya Kusuma 5(2) : 18-21

\title{
Kondiloma Akuminata
}

\author{
Diana Tri Ratnasari ${ }^{{ }^{*}}$ \\ Bagian Kulit dan Kelamin, Fakultas Kedokteran Universitas Wijaya Kusuma Surabaya ${ }^{1}$ \\ *email: dtratnasari@gmail.com
}

\begin{abstract}
Abstrak
Kondiloma akuminata (KA) atau lebih dikenal dengan penyakit kutil kelamin atau jengger ayam merupakan penyakit infeksi area genital yang disebabkan oleh human papiloma virus (HPV). Di Indonesia, angka kejadian KA terus bertambah dan merupakan penyakit ke tiga terbesar dari infeksi menular seksual. Kemungkinan tertular melalui hubungan seksual dengan pasangan yang terinfeksi HPV baik dalam bentuk subklinis adalah sebesar $75 \%$. Infeksi HPV genital pada umumnya mengenai mukosa yang lembab. Abrasi mikroskopi dan trauma berulang dapat meningkatkan infektivitas dan replikasi virus. Masa inkubasi HPV anatara 8 minggu samai 9 bulan. Umumnya tidak menimbulkan keluhan namun bentuknya dapat menyebabkan stres psikologik. Gambaran klinis KA cukup khas, teradapat 3 bentuk klinis yaitu berbentuk akuminata, keratosis, dan papul. Periode laten dapat berlangsung bberapa bulan sampai dengan tahun. Diagnosis ditegakkan pada umumnya cukup dengan melihat gambaran klinis. Pemeriksaan penunjang dilakukan apabila gambaran lesi tidak khas atau curiga keganasan. Tes asam asetat $5 \%$ dapat digunakan untuk melihat KA subklinis. Histopatologi dibutuhkan bila curiga keganasan. Pearly papule peniles merupakan varian normal yang memiliki gambaran mirip dengan KA dan tidak perlu diterapi. Penatalaksanaan KA dapat dilakukan dengan oles tinktura podofilin $25 \%$, TCA $80 \%-90 \%$, imiquimod $5 \%$, bedah eksisi, bedah listrik, dan bedah beku yang memberikan keberhasilan memuaskan. Terapi untuk ibu hamil paling aman dengan menggunakan TCA $80 \%-90 \%$.
\end{abstract}

Kata kunci: kondiloma akuminata, kutil kelamin, gambaran klinis, terapi

\section{Condyloma Accuminatum}

\begin{abstract}
Condyloma aaccuminatum (CA) or known as genital warts or chicken cockroach disease is a genital infections caused by human papilloma virus (HPV). In Indonesia, the incidence of CA continues to increase and is the third largest disease of sexually transmitted infections. The possibility of sexually transmitted infections with HPV-infected partners either in subclinical form is $75 \%$. Genital HPV infection is commonly associated with moist mucosa. Microscopic abration and reccurent traumatic can increase infectivity and viral replication. HPV incubation period is between 8 weeks and 9 months. Generally does not cause a complaint but its form can cause psychological stress. Clinical features of CA is quite typical, there are 3 forms of clinical form of acuminata, keratosis, and papules. The latent period may last several months to years. Diagnosis is generally enforced simply by looking at the clinical picture. Investigations are performed if the lesions are not typical or suspicious of malignancy. A 5\% acetic acid test can be used to look at subclinical trains. Histopathology is required when suspicious of malignancy. Pearly papule peniles are normal variants that have a similar picture to $C A$ and do not need to be treated. Management of railways can be done with $25 \%$ tincture of podophylline 25\%, TCA $80 \%-90 \%$, imiquimod $5 \%$, surgical excision, electrical surgery, and frozen surgery that provides satisfactory success. Therapy for pregnant women most secure by using TCA $80 \%-90 \%$.
\end{abstract}

Keywords: Condyloma accuminata, genital warts, clinical manifestation, treatment

\section{PENDAHULUAN}

Kondiloma akuminata (KA) atau genital warts atau lebih dikenal oleh masyarakat awam dengan istilah penyakit kutil kelamin ataupun penyakit jengger ayam digolongkan dalam penyakit menular seksual yang disebabkan oleh Human Papiloma Virus (HPV) (1). Saat ini telah 
dikenal lebih dari 120 subtipe HPV, namun yang bertanggung jawab terhadap terjadinya KA yang tersering adalah subtipe 6 dan 11. Dan subtipe 16 dan 18 diduga mempunyai kecenderungan ongkogenik menjadi penyebab keganasan pada leher Rahim (2).

Angka kejadian KA semakin bertambah banyak bahkan melebihi herpes genital. Di Amerika serikat, data dari Center for Disease Control and Prevention tercatat ada lebih dari 19,7 juta kasus baru infeksi menular seksual (IMS) tiap tahun, dan 14,1 juta kasus merupakan infeksi HPV (3). Sedangkan pada penelitian tentang Infeksi Menular Seksual di 12 Rumah Sakit Pendidikan di Indonesia mulai tahun 20072011, kejadian KA menduduki peringkat ke 3 terbesar. Kondiloma akuminata menduduki peringkat pertama di 6 kota yaitu Medan, Jakarta, Bandung, Semarang, Jogja dan Denpasar dengan usia terbanyak didapatkan pada golongan usia 25-45 tahun (4). Di Divisi Penyakit Menular Seksual Unit Rawat Jalan Kesehatan Kulit dan Kelamin RSUD Dr. Soetomo Surabaya, insidensi KA pada tahun 2002 sebesar 94 kasus, tahun 2003 sebesar 67 kasus, dan tahun 2005 sebesar 75 kasus(5).

\section{PEMBAHASAN}

\section{Penularan Kondiloma Akuminata}

Transmisi HPV terjadi melalui kontak dengan lesi epitel yang tampak maupun dalam bentuk subklinis, dan/atau cairan genital yang mengandung HPV. Penularan infeksi HPV terutama melalui hubungan seksual (6). Bila seseorang melakukan hubungan seksual dengan pasangan yang telah terinfeksi HPV, maka kemungkinan akan tertular virus dan timbul KA adalah sebesar $75 \%$ (7). Kontak langsung dengan tangan atau tidak langsung melalui bendabenda yang terkontaminasi dengan HPV (fomites) dapat terjadi penularan, meskipun jarang terjadi. Penularan dari ibu ke anak melalui kanalis vagina saat melahirkan dapat menimbulkan lesi disaluran nafas bayi (8).

\section{Patogenitas Kondiloma Akuminata}

Infeksi HPV genital pada umumnya mengenai mukosa yang lembab dan berdekatan dengan epitel skuamosa serviks dan anus. Abrasi mikroskopi pada saat berhubungan seksual memudahkan pasangan yang terinfeksi HPV untuk menularkannya kepada pasangan yang belum terinfeksi. Trauma berulang dapat meningkatkan infektivitas dan replikasi virus (9). Virus akan memasuki sel epitel basal pejamu, melepaskan kapsul protein dan berada bersama sel pejamu sebagai circular episome. Selanjutnya virus akan berada dalam masa inkubasi laten selama 1-8 bulan, dan selama itu tidak nampak manifestasi klinis. Fase pertumbuhan aktif akan dimulai bila terjadi lesi pertama. Sampai sekarang belum diketahui pemicu perubahan bentuk laten menjadi infeksius, namun dipengaruhi oleh faktor pejamu, virus, dan lingkungan (10). Sistem imun seluler yang kompeten dibutuhkan untuk pembersihan HPV, namun masih menjadi tantangan untuk menghilangkan virus dari pejamu yang imunokompeten. HPV terlindung dari respon imun pejamu karena virus berlokasi didalam sel (11).

\section{Manifestasi Klinis}

Masa inkubasi KA berkisar antara 2 minggu hingga 9 bulan. Secara umum kelainan fisik mulai 2-3 bulan setelah kontak. Umumnya tidak menimbulkan keluhan namun bentuknya dapat menyebabkan stres psikologik. Selama masa infeksi aktif, HPV akan bereplikasi tanpa bergantung pada pembelahan sel pejamu dan akan memicu pejamu berproliferasi membentuk banyak lesi berupa kutil datar hingga papilar (10). Lesi dapat bertangkai atau melekat di dasar (sessile) dan kadang-kadang berpigmen. Terdapat 3 bentuk klinis KA, yaitu akuminata, keratotik, dan papul. Bentuk akuminata, lunak karena tidak berkeratin, berbentuk seperti kembang kol, terutama didaerah mukosa yang hangat, lembab dan tidak berambut sebagaimana. Bentuk keratotik, menyerupai kutil biasa, di daerah kering, kulit anogenital. Bentuk papul, didaerah dengan keratinisasi sempurna yaitu dibatang penis, bagian lateral vulva, perineum, perianus, permukaan halus, licin dan tersebar diskrit. Infeksi subklinis dapat terlihat seperti bercak putih (positif acetowhite) setelah dilakukan tes asam asetat 5\% (12).

Sebagian besar infeksi HPV bersifat sementara atau transient dan tidak terdeteksi lagi dalam waktu 2 tahun. Meskipun demikian, sekitar 30\% KA akan mengalami regresi dalam 4 bulan pertama infeksi (7). Periode laten bisa berlangsung beberapa bulan hinga tahun (9).

\section{Diagnosis Kondiloma Akuminata}


Diagnosis KA umumnya dapat ditegakkan berdasar gambaran klinis, pemeriksaan fisik dengan pencahayaan yang baik dan kaca pembesar.

\section{Pemeriksaan Penunjang Kondiloma Akuminata}

Pada kasus yang meragukan, dapat dilakukan pemeriksaan penunjang, antara lain :

1. Tes asam asetat

Tes dilakukan dengan aplikasi larutan asam asetat $5 \%$ pada lesi yang dicurigai. Dalam waktu 3-5 menit, lesi akan berubah menjadi putih (acetowhite).

2. Kolposkopi

Pemeriksaan dengan alat pembesaran optik (kolposkop) untuk melihat serviks dan traktus genitalis wanita agar tampak lebih jelas. Terkadang dilakukan bersamaan dengan tes asam asetat.

3. Pemeriksaan histopatologi.

Pemeriksaan ini tidak dianjurkan sebagai pemeriksaan rutin KA. Indikasinya adalah untuk bentuk lesi yang tidak khas, lesi tidak responsif terhadap terapi, dan curiga ganas (ditandai dengan pigmentasi, pertumbuhan cepat, fiksasi pada dasar lesi, perdarahan dan ulserasi spontan. Secara mikroskopis, lesi KA ditandai dengan gambaran koilosit (keratinosit berukuran besar dengan area halo dan vakuolisasi perinuklear). Pada epidermis terdapat akantosis, parakeratosis, dan rete redges yang memanjang.

4. Pemeriksaan dermoskopi

Alat ini dapat melihat lesi awal datar dan membantu membedakan dengan lesi liken planus, keratosis seboroik dan bowenoid. Pada lesi KA menunjukkan gambaran pola vaskular dan gambaran yang khas, berupa pola mosaik pada lesi awal yang masih datar dan ola menyerupai tombol (knoblike), serat menyerupai jari pada lesi papilomatosa.

5. Identifikasi genom HPV.

Pemeriksaan ini tidak dianjurkan untuk diagnosis infeksi HPV anogenital secara rutin. Seseorang dapat terinfeksi lebih dari 1 subtipe HPV. Pemeriksaan polymerase chain reaction (PCR) mampu mendeteksi DNA HPV dengan sensitivitas dan spesifisitas tinggi

\section{Diagnosis banding kondiloma akuminata}

Kondiloma akuminata harus dibedakan dari semua bentuk kelainan yang berbentuk papul didaerah genital. Beberapa lesi kulit yang menyerupai KA yaitu:

1. Pearly penile papules, secara klinis tampak papul berawarna sama dengan kulit, terkadang lebih putih, berukuran $1-2 \mathrm{~mm}$, tersebar diskrit, mengelilingi sulkus coronaries. Ini adalah varian normal dan tidak perlu diobati.

2. Kondiloma lata, merupakan salah satu bentuk sifilis stadium sekunder. Lesi berupa papul-papul dengan permukaan lebih halus dan bentuk lebih bulat dari KA.

3. Karsinoma sel skuamosa, merupakan keganasan dan kadang sulit dibedakan dengan KA. Perlu dilakukan pemeriksaan histopatologi.

\section{Penatalaksanaan akuminata}

kondiloma

Infeksi HPV bersifat subklinis dan laten, maka tidak terdapat terapi spesifik terhadap virus ini. Perawatan diarahkan pada pembersihan kutil - kutil yang tampak dan bukan pemusnahan virus. Perhatian pada kebersihan arena genital sangat penting karena kelembaban mendukung pertumbuhan kutil. Beberapa modalitas terapi yang dapat dilakukan(2,12):

1. Tinktura podofilin $\mathbf{1 0 - 2 5 \%}$

Podofilin resin bekerja sebagai anti mitotik yang menginduksi nekrosis jaringan. Pada satu sesi terapi hanya diperbolehkan meliputi area seluas $10 \mathrm{~cm}^{2}$ atau jumlah podofilin kurang dari $0,5 \mathrm{ml}$. Tidak boleh diberikan pada ibu hamil.

2. Larutan trichloroacetic acid (TCA) $80-95 \%$

Bahan ini bersifat korosif dan dengan cepat menjadi inaktif setelah kontak dengan kulit/lesi. Aman digunakan untuk ibu hamil dan menggunakan konsentrasi 50\% ternyata juga memberikan hasil yang memuaskan. Komplikasi yang mungkin terjadi adala erosi dan ulkus dangkal.

3. Imiquimod 5\%. Imidazoquilinamine tidak memiliki anti virus in vitro namun dapat memodifikasi respon imun pejamu melalui peningkatan produksi sitokin interferon- $\alpha$, tumor necrosis factor (TNF), dan interleukin sehingga sel natural killer (NK cell), sel PMN, makrofag, dan sel T yang bersifat anti tumor mampu mengeradikasi virus. Obat ini tidak dapat digunakan pada membran mukosa dalam (uretra, vagina dan serviks) dan tidak 
boleh untuk ibu hamil. Sayangnya obat ini belum tersedia di Indonesia.

4. Bedah eksisi. Terutama untuk KA besar dan menimbulkan obstruksi. Lesi dapat diambil secara keseluruhan dalam 1 sesi terapi. Efek samping berupa nyeri, perdarahan, sampai timbul jaringan parut.

5. Bedah listrik. Dapat digunakan untuk lesi internal maupun eksternal. Keuntungan dan komplikasi sama dengan bedah eksisi.

6. Bedah beku. Menggunakan $\mathrm{N}_{2}$ cair, $\mathrm{CO}_{2}$ padat, cryoprobe untuk membekukan kandungan air jaringan sehingga terjadi lisis sel.

\section{KESIMPULAN}

Kondiloma akuminata merupakan penyakit infeksi daerah genital yang disebabkan oleh HPV. Angka kejadian KA semakin lama makin bertambah bahkan melebihi herpes genital. Penularan KA terutama melalui hubungan seksual. Trauma berulang dapat meningkatkan infektivitas dan replikasi virus. Masa inkubasi KA bervariasi antara 2 minggu sampai 9 bulan. Gambaran klinis KA khas dengan bentuk akuminata, keratotik dan papul. Diagnosis ditegakkan cukup dengan melihat gambaran klinis. Pemeriksaan penunjang dibutuhkan bila gambaran lesi meragukan atau curiga keganasan. Pearly penile papules merupakan variasi normal dari glan penis yang memiliki gambaran mirip KA. Penatalaksanaan dapat dilakukan oles tinktura podofilin $25 \%$. TCA 80\%-90\% dapat diberikan untuk ibu hamil. Bedah eksisi, bedah listrik, bedah beku merupakan penatalaksanaan yang memberikan hasil memuaskan dalam sekali sesi.

\section{DAFTAR PUSTAKA}

1. Yanofsky VR, Patel RV, Goldenberg G. 2012. Genital Warts A Comprehensive Review. The Journal of Clinical Aesthetic Dermatology. 5(6):25-36

2. Daili SF, Indriatmi W, Zubier F, Nilasari H. 2015. Infeksi Menular Seksual, Pedoman Praktis Diagnosis dan Tatalaksana. Kementrian Kesehatan RI. 29-30

3. Centers for Disease Control and Prevention: Incidence, Prevalence, and Cost of Sexually Transmitted Infections in the United State. 2013.
http://www.cdc.gov/std/stats/STI-

Estimates-Fact-Sheet-Feb-2013.pdf

4. Indriatmi. W. Epidemiologi Infeksi Menular Seksual. 2012. dibawakan pada Simposium Sexually_Transmitted Infections A rising concern 15-16 September 2012 Semarang

5. Wahyuni HN, Yusuf A, Barakbah J. 2006. Penderita kondilomata akuminata di Divisi Penyakit Menular Seksual Unit Rawat Jalan Ilmu Kesehatan Kulit dan Kelamin RSUD Dr. Soetomo Surabaya Periode 2002- 2005. BIPKK .18(3): 185-199

6. Pattman R, Sankar KN, Elawad B, Handy P, Price DA. 2010. Oxford Handbook of Genitourinary Medicine, HIV, and Sexual Health. Edisi ke 2. Oxford University Press, New York

7. Yanofsky VR, Patel RV, Goldenberg G. 2012. Genital Warts. Comprehensive review. J Clin Aesthet Dermatol. 5(6): 25-36

8. Schiffman M, Kjaer SK.2003. Natural Historyof anogeital human papiloma virus infection and neoplasia. J Nat Cancer Inst Monographs. 31: 14-19

9. Gunter J. 2003. Genital and perianal warts: new treatments opportunities for human papiloma virus_infection. Am J Obstet Gynecol. 189:S3-S11

10. Goldman LC, Clouse AL.2013. Human papilomavirus and genital warts. Dalam: Editor, Skolnik NS, Clouse AL, Woodward JA. Sexually transmitted diseases. A practical guide for primarycare. $2^{\text {nd }}$ ed. Humana Press, New York. 1-17

11. Arany I, Evans T, Tyring SK. 1998. Tissue specificsHPV epression and downregulation of local immune responses in condylomas from HIV seropositive individuals. Sex Transmf Inf. 74: 349-353

12. Djuanda A. Penyakit Virus. In: Djuanda A, Hamzah M, Aisah S, editors. 2013. Ilmu Penyakit Kulit dan Kelamin. Edisi ke 6. Fakultas Kedokteran Universitas Indonesia, Jakarta. 112-114

13. Yenny SW, Hidayah R. 2013. Kondiloma Akuminata Pada Wanita Hamil: Salah Satu Modalitas Terapi. Jurnal Kesehatan Andalas. 2(1) :47-50 